\title{
Perceived Employability and Career Adaptability of Engineering Graduates
}

\author{
Sílvia Monteiro \\ CIEd, Institute of Education \\ University of Minho \\ Braga, Portugal \\ silviamonteiro@ie.uminho.pt
}

\author{
Rosa M. Vasconcelos \\ 2C2T, University of Minho \\ Guimarães, Portugal \\ rosa@det.uminho.pt
}

\author{
Leandro Almeida \\ CIEd, Institute of Education \\ University of Minho \\ Braga, Portugal \\ leandro@ie.uminho.pt
}

\begin{abstract}
The new demands of the labor market have led to the emergence of more comprehensive and complexes employability models, including not only a set of skills determining employability but also a subjective dimension that integrates personal beliefs and attitudes. Besides that, there is also evidence that individuals' psychological resources, namely in terms of career adaptability, are significantly associated with further employability. In this paper, we present data on the perceptions of employability (four dimensions: my university, my study field, the labor market, and self-efficacy) and on the adaptability resources (concern, control, curiosity and confidence) of master's final-year students $(n=362)$, comparing a group of engineering students with students from other study fields (Social Sciences and Humanities and Economics). Regarding the perceptions of employability, the obtained results demonstrate that engineering graduates present more positive perceptions in the dimensions of study field and of external labor market, comparing with their colleagues from other fields. Concerning career adaptability resources, the differences are reversed, with engineering students with scoring lower in the dimensions of concern and confidence.
\end{abstract}

Keywords - engineering education, employability, career adaptability

\section{INTRODUCTION}

In a time when new skills are need to meet the challenges of globalization and impact of technological development on the labor market, graduates need to be equipped with more than technical skills. The new demands implies the ability to apply skills in professional contexts, according to the specific demands of each situation; also, they place a strong emphasis on self-awareness, as well as on the job market [1]-[3]. As claimed by Stawiski, Germuth, Yarborough, Alford and Parrish (2017) [4], "technical knowledge is important, but not exclusively so", and for this reason engineering educators have been criticized for a strong emphasis on scientific theory and technical knowledge and little attention on more comprehensive or psychosocial skills [5]. The $21^{\text {st }}$ century demands imply the ability to adapt to the diversity of job activities emerging over time, as well as the ability to solve complex problems that require the mobilization of a wide range of skills that need to be learned and continuously developed throughout professional career [6].

In this context, current employability models are comprehensive and complex, including not only a set of skills determinants of employability, but also a subjective dimension that integrates personal beliefs and attitudes [2], [3]. A close interaction between personal characteristics and the environment is assumed as a requirement to be 'employable' [7]. The concept of employability includes an internal dimension, related with person-specific factors like vocational and specific job skills [8] or the potential to learn [9], and an external dimension, usually referred to the state of the external labor market [10]. The integration of these two sets of factors are the basis of the concept of self-perceived employability [10]-[13]. This subjective dimension of employability has been empirically associated with the objective dimension, namely in terms of employment rates [14].

To be employable, individuals must be active agents in shaping their career, because they need to be able to recognize and demonstrate their competencies and interests, and also to explore and adjust strategies in order to find the intended employment. For this reason, employability implies a sense of career agency, requiring effort, self-knowledge and confidence [15]. Career adaptability is a psychosocial construct that integrates individuals' resources to manage career transitions. Adaptable people are able to adjust strategies, adaptive behaviors to change knowledge, skills, abilities, and other characteristics to meet situational challenges [7], [16], [17]. Hence, some authors have conceptualized career adaptability as a key element for the understanding of employability as it enables individuals to identify and realize career opportunities [7], [18]. Previous empirical studies have evidenced positive relations between career adaptability and perceptions of employability, skills or capacities [19]-[24] and the ability to find a job [25].

To understand graduates' employability, it is crucial to adopt a holistic view, which integrates individual and contextual factors, according with the reality of each area of professional activity. Therefore, the aim of this study is to describe the perceptions of employability and career adaptability resources in engineering students, comparing with students from other study fields. 


\section{METHOD}

\section{A. Participants}

Participants of this study are 362 final-year students of Masters' courses from Economics (25\%), Social Sciences and Humanities (31\%), and Engineering (44\%), from a from a Portuguese public university. The average age of the participants is $24.01(\mathrm{SD}=5.79)$. Fifty-seven percent of the participants are female, and $43 \%$ are male.

\section{B. Procedures}

Participants voluntarily completed the questionnaires in classroom context at the end of the school year. The aims of the study were explained orally and in writing. Conditions of confidentiality of the collected data were ensured.

\section{Measures}

Career Adapt-Abilities Scale (CAAS) was used to measure participants' career adaptability resources. The scale was originally developed by Savickas and Porfeli (2012) [26], and is composed by four subscales: concern - awareness of and planning for a vocational future (item example: 'Becoming aware of the educational and career choices that I must make'); control - self-discipline used by individuals in order to shape themselves and their environment to tackle challenges (item example: 'Making decisions by myself'), curiosity - propensity for exploration of diverse selves and contextual situations (item example: 'Observing different ways of doing things'), and confidence - self-efficacy in pursuing career aspirations and in managing career choices (item example: 'Learning new skills'). Each of the subscales comprises 6 items, and participants responded on a 5-point Likert scale ranging from 1 (Strongly disagree) to 5 (Strongly agree). The overall alpha coefficient of the CAAS obtained in this study was 0.92 , while the subscale scores were 0.81 for concern, 0.78 for control, 0.84 for curiosity, and 0.86 for confidence. Model fitvalues were $\chi 2 / \mathrm{df}=2.07$; GFI $=0.90$; $\mathrm{CFI}=0.93 ; \mathrm{RMSEA}=0.05[0.05-0.06]$.

Self-Perceived Employability Scale (SPES) was used to measure participants' perceived employability. The scale was originally developed by Rothwell, Herbert, and Rothwell (2008) [12]. This scale has a total of 13 items formulated in a Likert response format ranging from 1 (Strongly disagree) to 5 (Strongly agree), representing 4 subscales: My University students' perception of the strengths of their university in terms of its reputation (4 items, item example: 'Employers are eager to employ graduates from my university'); My Study Field - referring to the status and credibility of graduates' field of study ( 2 items, item example: 'My degree is seen as leading to a specific career that is generally perceived as highly desirable'); External Labour Market - regarding perception of the state of the external labour market (4 items, item example: 'There is generally a strong demand for graduates at the present time'); and Self-Belief - referring to graduates' engagement with their studies and academic performance, together with confidence in their own skills and abilities (3 items, item example: 'I feel I could get any job so long as my skills and experience are reasonably relevant'). Alpha coefficients obtained for the four subscales in this study were $0.76,0.77,0.82$, and 0.72 , respectively. Model fit values were $\chi 2 / \mathrm{df}=2.31$; GFI $=0.95$; CFI $=0.95$; $\mathrm{RMSEA}=0.06[0.05$ $0.07]$.

\section{RESULTS}

Table I presents the obtained data regarding career adaptability resources, comparing engineering students with their peers from other study fields. Despite the general results to show positive scores for career adaptability resources (above the midpoint of the scale) for the all participants, significant difference between study fields in two of the four subscales of career adaptability: concern and confidence. The post-hoc tests conducted (Sheffé), demonstrate that differences were specifically between engineering and economics' students, in both dimensions, with engineering participants scoring lower.

TABLE I.

DESCRIPTIVE STATISTICS AND TEST OF BETWEEN-SUBJECT EFFECTS FOR CAREER ADAPTABILITY DIMENSIONS

\begin{tabular}{|c|c|c|c|c|c|}
\hline Dimension & Study Field & Mean & SD & $\mathbf{F}$ & $p$ \\
\hline \multirow{3}{*}{ Concern } & Economics & 4.10 & .51 & \multirow{3}{*}{6.237} & \multirow{3}{*}{.002} \\
\hline & $\begin{array}{l}\text { Social } \\
\text { Sciences and } \\
\text { Humanities }\end{array}$ & 3.95 & .54 & & \\
\hline & Engineering & 3.83 & .59 & & \\
\hline \multirow{3}{*}{ Control } & Economics & 4.23 & .56 & \multirow{3}{*}{.174} & \multirow{3}{*}{.840} \\
\hline & $\begin{array}{l}\text { Social } \\
\text { Sciences and } \\
\text { Humanities }\end{array}$ & 4.18 & .44 & & \\
\hline & Engineering & 4.21 & .54 & & \\
\hline \multirow{3}{*}{ Curiosity } & Economics & 4.05 & .54 & \multirow{3}{*}{.581} & \multirow{3}{*}{.560} \\
\hline & $\begin{array}{l}\text { Social } \\
\text { Sciences and } \\
\text { Humanities }\end{array}$ & 3.95 & .51 & & \\
\hline & Engineering & 3.98 & .78 & & \\
\hline \multirow{3}{*}{ Confidence } & Economics & 4.28 & .53 & \multirow{3}{*}{3.074} & \multirow{3}{*}{.047} \\
\hline & $\begin{array}{l}\text { Social } \\
\text { Sciences and } \\
\text { Humanities }\end{array}$ & 4.19 & .46 & & \\
\hline & Engineering & 4.11 & .58 & & \\
\hline
\end{tabular}

Table II presents the obtained data concerning selfperceived employability dimensions, comparing engineering students with their peers from other study fields. Overall, scores are above the midpoint of the scale, with higher scores for the dimension of my university (all the study fields) and lower scores for the dimension of external labor market (in the case of engineering participants). After conducting the Post-hoc tests (Sheffé), it was verified that engineering students scored higher and significantly different from their colleagues of Economics and Social Sciences and Humanities, in the dimension of my study field and external labor market.

TABLE II.

DESCRIPTIVE STATISTICS AND TEST OF BETWEEN-SUBJECT EFFECTS FOR SELF-PERCEIVED EMPLOYABILITY DIMENSIONS

\begin{tabular}{|c|c|c|c|c|c|}
\hline Dimension & Study Field & Mean & SD & $\mathbf{F}$ & $p$ \\
\hline \multirow{3}{*}{$\begin{array}{l}\text { My } \\
\text { university }\end{array}$} & Economics & 3.77 & .53 & \multirow{3}{*}{1.321} & \multirow{3}{*}{.268} \\
\hline & $\begin{array}{l}\text { Social Sciences } \\
\text { and Humanities }\end{array}$ & 3.79 & .64 & & \\
\hline & Engineering & 3.87 & .55 & & \\
\hline \multirow{3}{*}{$\begin{array}{l}\text { My study } \\
\text { field }\end{array}$} & Economics & 3.44 & .65 & \multirow{3}{*}{41.268} & \multirow{3}{*}{.000} \\
\hline & $\begin{array}{l}\text { Social Sciences } \\
\text { and Humanities }\end{array}$ & 2.84 & .88 & & \\
\hline & Engineering & 3.69 & .71 & & \\
\hline
\end{tabular}




\begin{tabular}{|c|c|c|c|c|c|}
\hline Dimension & Study Field & Mean & SD & $\mathbf{F}$ & $p$ \\
\hline \multirow{3}{*}{$\begin{array}{l}\text { External } \\
\text { Labour } \\
\text { Market }\end{array}$} & Economics & 2.96 & .62 & \multirow{3}{*}{59.227} & \multirow{3}{*}{.000} \\
\hline & $\begin{array}{l}\text { Social Sciences } \\
\text { and Humanities }\end{array}$ & 2.55 & .75 & & \\
\hline & Engineering & 3.49 & .70 & & \\
\hline \multirow{3}{*}{ Self-Belief } & Economics & 3.53 & .65 & \multirow{3}{*}{2.456} & \multirow{3}{*}{.087} \\
\hline & $\begin{array}{l}\text { Social Sciences } \\
\text { and Humanities }\end{array}$ & 3.41 & .64 & & \\
\hline & Engineering & 3.58 & .57 & & \\
\hline
\end{tabular}

\section{Discussion AND CONCLUSIONS}

The world has been changing rapidly over the last decades, especially due to the rapid technological development. Consequently, the world become a more complex place, with new organizational forms and requiring strong ability to mobilize knowledge and skills [6]. In a publication of the World Economic Forum from 2016, it was estimated that technological trends would bring an unprecedented rate of change in the core curriculum content of several academic fields, with nearly $50 \%$ of subject knowledge acquired during the first year of a technical degree outdated by the time students graduate. Also, the need to develop sustainable practices is changing rapidly and requiring new ways of acting in engineering [27]. This means that, it might not be enough to concentrate efforts on the type of skills that should be developed during the education of future engineers; it is also important to pay attention to students' psychological resources that potentiate the continuous development of the knowledge and skills to deal with these new demands placed on the professional practice of engineers.

Our study evaluates graduates' perceptions of their employability, taking into account their ability to cope with these new demands on the professional world today and, simultaneously, to higher education institutions. Taking the obtained results, engineering students demonstrate higher perceived employability, comparing with their peers from other study fields. Nevertheless, they showed less career adaptability resources, namely concern - awareness of and planning for a vocational future - and confidence - selfefficacy in pursuing career aspirations and in managing career choices.

Apparently, positive perceptions of employability result from more favorable circumstances for engineering and technological areas in terms of labor supply than from personal resources of these students. This is particularly evident from the positive differentiation of engineering students in the subscales of study field and external labor market. That is, despite engineering graduates being less optimistic in relation to the impact of the general labor market, they seem more confident in relation to the contribution of the chosen area for their employability. Nevertheless, although engineer graduates do not demonstrate many concerns about entry to the labor market, they perceive themselves as less agile in managing their career throughout their professional activity. This can be particularly problematic at a time when the labor market is in continuous change and requires a rapid response and adaptation capacity. Furthermore, the technological areas in which engineers typically operate require a great capacity for innovation and creativity, which also implies the ability to monitor and mobilize resources and skills in order to be successful in the area.

These results raise practical implications for engineering education, which should go beyond technical and transversal skills, but also focusing on the ability to learn to learn and, simultaneously, on career management. In an comprehensive way, Brigstock (2009) [28] refers to career management for maximum employability as "an ongoing process of engaging in reflective, evaluative and decision-making processes using skills for self- management and career building, based on certain underlying traits and dispositional factors, to effectively acquire, exhibit and use generic and disciplinespecific skills in the world of work" (p. 35). Although there seem not to exist a "one-size-fits-all" model for the development of such skills, some theoretical references and practical experiences have been proposed in the literature [28]-[30]. This type of intervention should be adjusted to the reality of each context, taking into account the curriculum goals defined in each program and the existing institutional and community resources.

\section{LIMITATIONS AND FUTURE DIRECTIONS}

This study has several limitations that should be taken into consideration. First, only one university was considered in this study, and so the results should not be generalized to different contexts. It is possible that the inclusion of students from different university contexts would have resulted in different findings due to the increase of the sample variance. Second, data presented in this paper only considered students' perceptions of their employability and career adaptability resources. Future studies should also consider to integrate objective measures together with subjective measures of employability, in order to obtain a broader and in-depth look at the issues of employability. Lastly, longitudinal study of graduates, assessing the relationship of the self-perceived employability, career adaptability resources with the continuous development of skills, problem-solving capacity and career progression would be a pertinent and elucidative focus for the area of engineering education.

\section{ACKNOWLEDGMENT}

This work was supported by the Fundação para a Ciência e a Tecnologia [SFRH/BPD/92331/2013] and by CIEd -

Research Centre on Education, projects

UID/CED/1661/2013, UID/CED/1661/2016, Institute of Education, and Project UID/CTM/00264/2019 of 2C2T Centro de Ciência e Tecnologia Têxtil , University of Minho, through national funds of FCT/MCTES-PT.

\section{REFERENCES}

[1] N. Bennett, E. Dunne, and C. Carré, "Patterns of core and generic skill provision in higher education," High. Educ., vol. 37, no. 1, pp. 71-93, 1999.

[2] L. D. Pool and P. Sewell, "The key to employability: developing a practical model of graduate employability," Educ. + Train., vol. 
49, no. 4, pp. 277-289, 2007.

[3] M. Yorke and P. Knight, Embedding employability into the curriculum. Learning and Employability Series 1. York: Higher Education Academy., 2004.

[4] S. Stawiski, A. Germuth, P. Yarborough, V. Alford, and L. Parrish, "Infusing Twenty-First-Century Skills into Engineering Education," J. Bus. Psychol., vol. 32, no. 3, pp. 335-346, 2017.

[5] J. V. Farr and D. M. Brazil, "Leadership skills development for engineers," EMJ - Eng. Manag. J., vol. 21, no. 1, pp. 3-8, 2009.

[6] J. Allen and R. van der Velden, Skills for the 21st century: Implications for education. Maastricht: ROA: Maastricht University School of Business and Economics, 2012.

[7] M. Fugate, A. J. Kinicki, and B. E. Ashforth, "Employability: A psycho-social construct, its dimensions, and applications," $J$. Vocat. Behav., vol. 65, no. 1, pp. 14-38, Aug. 2004.

[8] J. Hillage and E. Pollard, Employability: Developing a framework for policy analysis. London: DfEE, 1998.

[9] D. Lane, A. Puri, P. Cleverly, R. Wylie, and A. Rajan, Employability: Bridging the gap between rhetoric and reality: Employee's perspective. London, England: Create, 2000.

[10] A. Kirschenbaum and R. Mano-Negrin, "Underlying labor market dimensions of 'opportunities': The case of employee turnover," Hum. Relations, vol. 52, no. 10, pp. 1233-1255, Oct. 1999.

[11] A. Rajan, "Employability in the finance sector: rhetoric vs reality," Hum. Resour. Manag. J., vol. 7, no. 1, pp. 67-78, Jan. 1997.

[12] A. Rothwell, I. Herbert, and F. Rothwell, "Self-perceived employability: Construction and initial validation of a scale for university students," J. Vocat. Behav., vol. 73, no. 1, pp. 1-12, 2008.

[13] A. Rothwell and J. Arnold, "Self perceived employability: development and validation of a scale," Pers. Rev., vol. 36, no. 1, pp. 23-41, Jan. 2007.

[14] L. Caricati, R. Chiesa, D. Guglielmi, and M. G. Mariani, "Real and perceived employability: a comparison among Italian graduates," J. High. Educ. Policy Manag., vol. 38, no. 4, pp. 490-502, 2016.

[15] M. L. Savickas, "New Questions for Vocational Psychology: Premises, Paradigms, and Practices," J. Career Assess., vol. 19, no. 3, pp. 251-258, Jan. 2011.

[16] A. Lo Presti, "Snakes and ladders: stressing the role of metacompetencies for post-modern careers," Int. J. Educ. Vocat. Guid., vol. 9, no. 2, pp. 125-134, Mar. 2009.

[17] M. L. Savickas, "Career construction theory and practice," in Career development and counseling: Putting theory and research to work, S. D. Brown and R. W. Lent, Eds. Hoboken, NJ: Wiley, 2013, pp. 147-183.

[18] M. Tomlinson, "Forms of graduate capital and their relationship to graduate employability," Educ. + Train., vol. 59, no. 4, pp. 338352, Apr. 2017.

[19] M. Coetzee, N. Ferreira, and I. L. Potgieter, "Assessing employability capacities and career adaptability in a sample of human resource professionals," J. Hum. Resour. Manag., vol. 13, no. $1,2015$.

[20] A. B. de Guzman and K. O. Choi, "The relations of employability skills to career adaptability among technical school students," $J$. Vocat. Behav., vol. 82, no. 3, pp. 199-207, Jun. 2013.

[21] V. Gamboa, O. Paixão, and A. I. Palma, "Career adaptability and self-efficacy in school-work transition: the role of the perceived employability -a study with Higher Education students," Rev. Port. Pedagog., vol. 48, no. 2, pp. 133-156, 2014.

[22] C. W. Rudolph, K. N. Lavigne, I. M. Katz, and H. Zacher, "Linking dimensions of career adaptability to adaptation results: A meta-analysis," J. Vocat. Behav., vol. 102, no. October 2016, pp. 151-173, 2017.

[23] C. W. Rudolph, K. N. Lavigne, and H. Zacher, "Career adaptability: A meta-analysis of relationships with measures of adaptivity, adapting responses, and adaptation results," J. Vocat. Behav., vol. 98, pp. 17-34, 2017.

[24] D. Spurk, S. Kauffeld, A. L. Meinecke, and K. Ebner, "Why Do Adaptable People Feel Less Insecure? Indirect Effects of Career Adaptability on Job and Career Insecurity via Two Types of Perceived Marketability," J. Career Assess., vol. 24, no. 2, pp. 289-306, May 2016.

Y. Guan et al., "Career adaptability, job search self-efficacy and outcomes: A three-wave investigation among Chinese university graduates," J. Vocat. Behav., vol. 83, no. 3, pp. 561-570, Dec. 2013.

[26] M. L. Savickas and E. J. Porfeli, "Career Adapt-Abilities Scale: Construction, reliability, and measurement equivalence across 13 countries," J. Vocat. Behav., vol. 80, no. 3, pp. $661-673,2012$.

[27] C. I. Davidson et al., "Preparing future engineers for challenges of the 21 st century: Sustainable engineering," J. Clean. Prod., vol. 18, no. 7, pp. 698-701, 2010.

[28] R. Bridgstock, "The graduate attributes we've overlooked: Enhancing graduate employability through career management skills," High. Educ. Res. Dev., vol. 28, no. 1, pp. 31-44, Mar. 2009.

[29] R. G. Sultana, "Learning career management skills in Europe: a critical review," Journal of Education and Work, vol. 25, no. 2. pp. 225-248, 2012.

[30] The Higher Education Academy, "Personal development planning and employability Learning and Employability," 2009. 